\title{
Influence of Carbon Dioxide and Nitrogen Source on Sustainable Production of Succinic Acid from Miscanthus Hydrolysates
}

\author{
Mariusz Kuglarz and Monika Rom
}

\begin{abstract}
This study presents sustainable succinic acid production from lignocellulosic hydrolysates, using A. succinogenes, which consumes $\mathrm{CO} 2$ during succinic fermentation. Optimal combination of carbon source (gaseous and/or solid $\mathrm{MgCO}_{3}, 15-30 \mathrm{~g} / \mathrm{dm}^{3}$ ) and nitrogen source (mixtures of yeast extract and hydrolyzed rapeseed cakes: 100:0, 80:20, 60:40, 50:50 and 40:60\% w/w) were experimentally determined. Obtained results stated that simultaneous addition of gaseous $\mathrm{CO}_{2}$ and $\mathrm{MgCO}_{3}\left(20-30 \mathrm{~g} / \mathrm{dm}^{3}\right)$ resulted in the highest sugar conversion (89-95\%) and succinic yields (66-74\%). Additionally, $\mathrm{CH}_{4}$ content in biogas, used as $\mathrm{CO}_{2}$ source, was increased by $21-22 \%$ and reached $91-92 \%$ after succinic fermentation with addition of $\mathrm{MgCO}_{3}\left(20 \mathrm{~g} / \mathrm{dm}^{3}\right)$. The course of succinic fermentation confirmed that $50 \%$ of nitrogen dosage can be added as rich in amino acids rapeseed cakes, originated from biodiesel production. Succinic fermentation with gaseous $\mathrm{CO}_{2}$ as the only $\mathrm{CO}_{2}$ or after replacing more than $50 \%$ of nitrogen dosage as rapeseed cakes, resulted in increased acetic and formic acids production (by-products of succinic fermentation). Optimal conditions of succinic fermentation $\left(\mathrm{CO}_{2}\right.$ source and dosage, waste nitrogen source) identified in this study can pave the way towards sustainable production of succinic acid from lignocellulosic biomass.
\end{abstract}

Index Terms - Succinic acid, biomass, hydrolysates after pretreatment, nitrogen source, carbon dioxide, biogas.

\section{INTRODUCTION}

Green technology is becoming a driving force in chemical industry because of the current need to decrease environmental impacts, caused by petrochemical industry. Succinic acid in particular, can be used as precursor for the production of biodegradable polymers, food, fine chemicals, green solvents and pharmaceuticals [1]. Succinic acid, also known as amber acid or butanedioic acid, has been recognized as one of the top twelve building-blocks chemicals [2]. Currently, this compound is mainly produced petro-chemically through hydrogenation of maleic anhydride, a process which is considered as a relatively expensive and contributes to environmental problems. Alternatively, bio-based production of succinic acid through microbial fermentation is considered as a very attractive, due to the fact that it can contribute to the abatement of $\mathrm{CO}_{2}$ emissions as

Manuscript received May 6, 2019; revised August 15, 2019. This work was supported by Polish Ministry of Science and Higher Education via Juventus Plus program for young scientists, conducting research at a high level and having outstanding scientific achievements. "The concept succinic acid production from lignocellulosic biomass using waste $\mathrm{CO} 2$ (0395/IP2/2016/74)" (public funds for science in the years 2016-2019),

The authors are with Faculty of Materials, Civil and Environmental Engineering, University of Bielsko-Biala, 43-309, Willowa 2, Bielsko-Biala, Poland (e-mail: mkuglarz@ath.bielsko.pl, mrom @ath.bielsko.pl). this gas is consumed during succinic fermentation [3], [4].

Among number of bacterial strains able to generate succinic acid through anaerobic fermentation, Actinobacillus succinogenes is considered as one of the most promising ones for industrial applications [5], [6], mainly due to its ability to ferment wide range of carbon sources, i.e. glucose, xylose, arabinose, galactose etc. [5]. However, effective production of succinic acid (building block chemical) from lignocellulosic hydrolysates, is strictly connected with the amount of sugars released during biomass hydrolysis (pre-treatment). According to the current state of knowledge, pretreatments with organic solvents are very effective in lignocellulosic biomass hydrolysis and lead to smaller sugar losses compared to most commonly used acid-based, alkali or oxidative methods [7]-[10]. Hydrolyzed biomass is converted into succinic acid through microbial fermentation (including Actinobacillus succinogenes) and carbon dioxide availability and nitrogen source constitute the most important parameters influencing effectiveness of succinic fermentation (sugar conversion rates, succinic yields). In particular, $\mathrm{CO}_{2}$ supply is the crucial factor determining succinic yield, the ratio of succinic acid to other by-products as well as the degree of sugar utilization. Besides carbon source, nitrogen source and its dosage have a direct impact on the economy of succinic fermentation. In most cases, yeast extract, being rich in amino acids, vitamins and trace elements is considered as favorable nitrogen source in fermentation processes. However, yeast extract is treated as one of the most expensive medium component and sustainable succinic acid production should eliminate or decrease its usage, by application of waste products, rich in amino acids.

This study presents sustainable succinic acid production from hydrolysates after glycerol-based pretreatment, using $A$. succinogenes $130 \mathrm{Z}$ (ATCC 55618). The aim of this study was to analyze the influence of carbon dioxide and nitrogen source on the effectiveness of succinic fermentation. Optimal combination of carbon source (gaseous and solid $\mathrm{MgCO}_{3}$ ) and nitrogen source (mixtures of yeast extract and rapeseed cake) were experimentally determined. According to best of our knowledge, this is the first study evaluating the usage of biogas after co-digestion processes $\left(\mathrm{CO}_{2}\right.$ source $)$ and rapeseed cakes (nitrogen source) for the production of succinic acid from real hydrolysates, obtained from lignocellulosic biomass.

\section{MATERIALS AND METHOD}

\section{A. Feedstock}

Hydrolysates $\left(35.6 \pm 0.7\right.$ g-glucose $/ \mathrm{dm}^{3}$ and $8.25 \pm 0.3$ 
g-xylose $/ \mathrm{dm}^{3}$ ) obtained after biomass pretreatment with glycerol-based method at optimized conditions $(80 \% \mathrm{w} / \mathrm{w}$ of waste glycerol after biodiesel production $+1.25 \% \mathrm{w} / \mathrm{v} \mathrm{H}_{2} \mathrm{SO}_{4}$ as a catalyst) and subsequent hydrolysis with the most effective enzymatic mixture (10\% w/w Cellic ${ }^{\circledR}$ CTec $2,5 \%$ w/w $\beta$-Glucanase and $1 \%$ w/w Cellic $®$ HTec 2 ) were used as feedstock for succinic acid production. Pretreatment conditions and dosage of enzymatic cocktails were established during our previous studies [11].

\section{B. Procedure of Succinic Fermentation}

Before fermentation, hydrolysates were autoclaved at $121^{\circ} \mathrm{C}$ for 20 minutes as well as mixed with experimental medium (nutrients) at 75:25 (v/v), which was selected as the most optimal ratio, based on our previous studies [12]. Succinic fermentation was conducted in triplicates, using identical $3 \mathrm{dm}^{3}$ fermenters (Sartorius BIOSTAT Aplus, Germany) with an initial working volume of $1.0 \mathrm{~L}$, operated at $37^{\circ} \mathrm{C}$ and $150 \mathrm{rpm}$ for $48 \mathrm{~h}$. In each case, about $5 \%(\mathrm{v} / \mathrm{v})$ of exponentially growing inoculum was added. The strain of $A$. succinogenes 130Z (DSM 22257) was obtained from DSMZ and was stored in glycerol at $-80{ }^{\circ} \mathrm{C}$ until used. Seed culture medium was composed of $\left(\mathrm{g} / \mathrm{dm}^{3}\right)$ : glucose $(10.0)$, yeast extract (5.0 or 10.0), $\mathrm{NaHCO}_{3}(10.0), \mathrm{NaH}_{2} \mathrm{PO}_{4} \cdot 2 \mathrm{H}_{2} \mathrm{O}$ (9.6), $\mathrm{K}_{2} \mathrm{HPO}_{4} \cdot 3 \mathrm{H}_{2} \mathrm{O}$ (20.3). During start-up of the process, $\mathrm{N}_{2}$ gas was used to create anaerobic conditions in fermenters. Prior to start of batch fermentation, $\mathrm{pH}$ was adjusted to 6.8 with $50 \%$ $\mathrm{H}_{3} \mathrm{PO}_{4}$ and $0.05 \mathrm{~mL}$ of sterile Antifoam 204 was added. In case of $\mathrm{pH}$ decrease below 6.8 during fermentation due to acid production and insufficient carbonate-bicarbonate buffering capacity, $\mathrm{NaOH}$ solution $(8 \mathrm{M})$ was added.

Two sets of succinic fermentation were conducted. Firstly, the influence of carbon dioxide source and dosage were taken into account. Solid $\mathrm{MgCO}_{3}\left(15-30 \mathrm{~g} / \mathrm{dm}^{3}\right)$ and biogas (containing $75 \%$ of $\mathrm{CH}_{4}$ and $25 \%$ of $\mathrm{CO}_{2}$ ) were used as carbon dioxide. The biogas originated from our previous sewage sludge and kitchen biowaste co-digestion experiments [13]. This part of experiment was conducted using 5:1 gas-liquid ratio and atmospheric pressure (101.3 $\mathrm{kPa}$ ). In order to increased $\mathrm{CO}_{2}$ solubility, the process was conducted at increased pressure, i.e. $(140 \mathrm{kPa})$. For monitoring the pressure inside fermenters, a pressure gauge was mounted with a relief valve. The biogas was recirculated during fermentation and changes in $\mathrm{CH}_{4}$ and $\mathrm{CO}_{2}$ concentrations were recorded. Considering the fact that gaseous $\mathrm{CO}_{2}$ exhibits a relatively poor solubility, biogas (containing $\mathrm{CO}_{2}$ ) was supplemented with solid $\mathrm{MgCO}_{3}$ $\left(15-30 \mathrm{~g} / \mathrm{dm}^{3}\right)$.

During the second set of succinic acid production, the impact of nitrogen source (yeast extract and/or rapeseed cakes after biodiesel production) was taken into account. The rapeseed cake dry matter (d.m.) content amounted to $950 \pm 20$ $\mathrm{g} / \mathrm{kg}$ and the main components of this substrate included: total protein $340 \pm 25 \mathrm{~g} / \mathrm{kg}$, cellulose $148 \pm 10 \mathrm{~g} / \mathrm{kg}$, hemicellulose $54.0 \pm 5.0 \mathrm{~g} / \mathrm{kg}$, insoluble lignin $150 \pm 8.5 \mathrm{~g} / \mathrm{kg}$, ash $48.2 \pm 2.5 \mathrm{~g} / \mathrm{kg}$. Total amino acid content in cakes before hydrothermal processing amounted to $310 \pm 10 \mathrm{~g} / \mathrm{kg}$. The hydrothermolysis of rapeseed cake was performed in a batch reactor (Minotavr-1), at $210-220{ }^{\circ} \mathrm{C}$, which is in consistent with previous studies on effective amino acids conversion from rapeseed cakes [14]. The fermentation was conducted using the following ratios of yeast extract and rapeseed cake ( $\%$ w/w): 100:0, 80:20, 60:40, 50:50 and 40:60. Nitrogen dosage (yeast extract and/or rapeseed cakes) amounted to 5 and 10 $\mathrm{g} / \mathrm{dm}^{3}$, which is in the range commonly used for succinic fermentation, using A. succinogenes [3], [11]-[13].

One milliliter samples were taken periodically (after $0,3,6$, $12,15,18,24,30,36$ and $48 \mathrm{~h}$ ) and used for analysis of sugars (glucose, xylose), and acids (succinic-, acetic- and formic). Succinic acid yield $\left(\mathrm{Y}_{\mathrm{SA}}\right)$ was calculated as the amount of succinic acid $\left(\mathrm{g} / \mathrm{dm}^{3}\right)$ obtained per $1 \mathrm{~g} / \mathrm{dm}^{3}$ of sugars (glucose + xylose) consumed. Sugar utilization was calculated as the difference between initial sugar content $\left(\mathrm{g} / \mathrm{dm}^{3}\right)$ and sugar content after succinic acid production $\left(\mathrm{g} / \mathrm{dm}^{3}\right)$.

\section{Analytical Methods}

Concentrations of sugars and organic acids (succinic, acetic, formic) were measured by using high performance liquid chromatography HPLC (Agilent 1260 Infinity, Germany) equipped with a Bio-Rad Aminex HPX-87H column at $63{ }^{\circ} \mathrm{C}$ and ultraviolet (UV) and refractive index (RI) detector (67162A, Germany), using $4 \mathrm{mM} \mathrm{H}_{2} \mathrm{SO}_{4}$ as eluent at $0.6 \mathrm{~mL} / \mathrm{min}$ flow rate. The $\mathrm{pH}$ was measured using a standard $\mathrm{pH}$ meter. All chemicals used in this study were of analytical grade. Dissolved carbon dioxide content in fermentation broths was determined using an InPro 5000i sensor coupled with Mettler Toledo (M400).

All results are presented as average values were compared statistically. One-way ANOVA test followed by HSD tests were used for multiple comparisons between samples, with the level of significant set at 0.05 . The same letters represent data equivalent statistically $(p>0.05)$.

\section{RESULTS AND DISCUSSION}

\section{A. Succinic Fermentation Using Different Carbon Sources}

Carbon dioxide constitutes one of the major substrates used for biosynthesis of succinic acid, while, $\mathrm{CO}_{2}$ source and dosage influence the metabolic flux as well as effectiveness of succinic acid production [15]. Firstly, the succinic acid fermentation was conducted, using gaseous $\mathrm{CO}_{2}$ (biogas containing $75 \% \mathrm{CH}_{4}$ and $\left.25 \% \mathrm{CH}_{4}\right)$. The process conducted at atmospheric pressure $\left(101.3 \mathrm{kPa}, \mathrm{CO}_{2}\right.$ partial pressure 40 $\mathrm{kPa}$ ) allowed to utilize about $55 \%$ of available sugars (glucose and xylose) and resulted in a relatively low succinic yield - 54\% (0.54 g-succinic acid/g-sugar consumed (Table I, Figure 1). Process conducted at increased pressure, i.e. 140 $\mathrm{kPa}\left(\mathrm{CO}_{2}\right.$ partial pressure of $\left.56 \mathrm{kPa}\right)$ and thus at higher $\mathrm{CO}_{2}$ solubility [6], had no significant impact on sugar utilization, whereas, succinic yield was increased by $7 \%$ (Table I). These succinic yields are slightly lower than yields previously reported, using model biogas mixture $\left(60 \% \mathrm{CH}_{4}\right.$ and $40 \%$ $\mathrm{CO}_{2}$ ). However, the current study was based on biogas containing significantly lower $\mathrm{CO}_{2}$ content (25\% vol.) compared to previous studies [6].

In many previous studies on bio-succinic acid production, salts $\left(\mathrm{MgCO}_{3}, \mathrm{NaHCO}_{3}\right.$ or $\left.\mathrm{CaCO}_{3}\right)$ are used as carbon source. In particular, $\mathrm{MgCO}_{3}$ was identified as the most effective $\mathrm{CO}_{2}$ supplier and $\mathrm{pH}$ control agent [4], [16].

In these cases, the highest succinic titers $\left(22-23 \mathrm{~g} / \mathrm{dm}^{3}\right)$ and yields (74-76\%) were obtained after addition of $25-30 \mathrm{~g} / \mathrm{dm}^{3}$ 
$\mathrm{MgCO}_{3}$ as carbon dioxide source (data equivalent statistically, data statistically equivalent, $p>0.05$ ) (Table I). It should also be highlighted that the degree of sugar conversion and succinic yields were improved by $67-70 \%$ and $37-40 \%$, respectively compared to the process with biogas as the $\mathrm{CO}_{2}$ source (Fig. 1). Significantly lower succinic titers and yields were obtained for $\mathrm{MgCO}_{3}$ dosage of $15-20 \mathrm{~g} / \mathrm{dm}^{3}$, which proved that availability of $\mathrm{CO}_{2}$ plays a crucial role during succinic acid biosynthesis and promotes the carbon flow towards SA production branch of TCA (tricarboxylic acid) cycle [3], [4].

TABLE I: INFLUENCE OF CARBON DIOXIDE SOURCE ON SUCCINIC ACID PRODUCTION

\begin{tabular}{||l||c||c||c||}
\hline \hline $\mathrm{CO}_{2}$ source & $\begin{array}{c}\text { Sugar util. } \\
(\%)\end{array}$ & $\begin{array}{c}\text { Succinic } \\
\text { yield }(\%)\end{array}$ & $\begin{array}{c}\text { Byproducts } \\
(\%)\end{array}$ \\
\hline \hline $\mathrm{Biogas}^{\mathrm{a}}(101.3 \mathrm{kPa})$ & $54.7 \pm 3.5 \mathrm{c}$ & $54.4 \pm 2.5 \mathrm{de}$ & $34.5 \pm 1.4 \mathrm{a}$ \\
\hline \hline $\mathrm{Biogas}(140 \mathrm{kPa})$ & $55.7 \pm 2.0 \mathrm{c}$ & $58.1 \pm 2.1 \mathrm{~cd}$ & $36.6 \pm 2.1 \mathrm{a}$ \\
\hline \hline $\mathrm{MgCO}_{3} 15 \mathrm{~g} / \mathrm{dm}^{3}$ & $74.2 \pm 2.6 \mathrm{~b}$ & $48.6 \pm 4.7 \mathrm{e}$ & $27.5 \pm 1.4 \mathrm{~b}$ \\
\hline \hline $\mathrm{MgCO}_{3} 20 \mathrm{~g} / \mathrm{dm}^{3}$ & $80.2 \pm 4.6 \mathrm{~b}$ & $63.1 \pm 2.2 \mathrm{~cd}$ & $28.5 \pm 1.5 \mathrm{bc}$ \\
\hline \hline $\mathrm{MgCO}_{3} 25 \mathrm{~g} / \mathrm{dm}^{3}$ & $91.4 \pm 0.9 \mathrm{a}$ & $74.3 \pm 2.4 \mathrm{ab}$ & $24.7 \pm 1.2 \mathrm{~d}$ \\
\hline \hline $\mathrm{MgCO}_{3} 30 \mathrm{~g} / \mathrm{dm}^{3}$ & $93.2 \pm 0.8 \mathrm{a}$ & $76.1 \pm 2.5 \mathrm{a}$ & $24.2 \pm 1.2 \mathrm{~d}$ \\
\hline \hline $\mathrm{CO}_{2}{ }^{\mathrm{a}}+15 \mathrm{~g} / \mathrm{dm}^{3} \mathrm{MgCO}_{3}$ & $79.3 \pm 3.8 \mathrm{~b}$ & $55.1 \pm 3.6 \mathrm{de}$ & $28.9 \pm 1.3 \mathrm{~b}$ \\
\hline \hline $\mathrm{CO}_{2}{ }^{\mathrm{a}}+20 \mathrm{~g} / \mathrm{dm}^{3} \mathrm{MgCO}_{3}$ & $89.3 \pm 1.5 \mathrm{a}$ & $65.7 \pm 3.0 \mathrm{bc}$ & $25.8 \pm 1.4 \mathrm{~cd}$ \\
\hline \hline $\mathrm{CO}_{2}{ }^{\mathrm{a}}+25 \mathrm{~g} / \mathrm{dm}^{3} \mathrm{MgCO}_{3}$ & $94.6 \pm 1.3 \mathrm{a}$ & $72.8 \pm 4.3 \mathrm{ab}$ & $25.9 \pm 1.3 \mathrm{~cd}$ \\
\hline \hline $\mathrm{CO}_{2}{ }^{\mathrm{a}}+30 \mathrm{~g} / \mathrm{dm}^{3} \mathrm{MgCO}_{3}$ & $94.2 \pm 1.9 \mathrm{a}$ & $73.7 \pm 3.9 \mathrm{ab}$ & $27.0 \pm 1.1 \mathrm{~cd}$ \\
\hline \hline
\end{tabular}

(a - fermentation with biogas as carbon dioxide source, conducted at pressure of $101.3 \mathrm{kPa}$, average values $n=3, \pm$ standard deviation, the same letters represent data equivalent statistically $p>0.05$ )
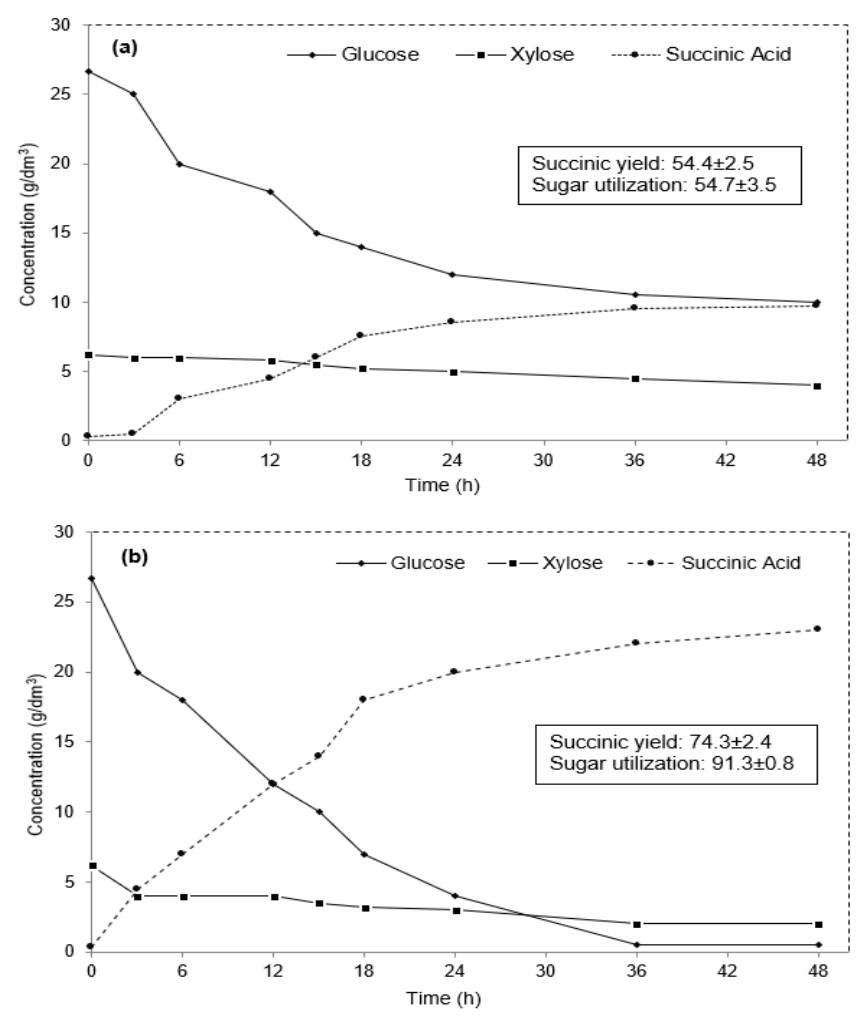

Fig. 1. Course of succinic acid fermentation (a- biogas used as carbon source, $101.3 \mathrm{kPa}$, yeast extract used as nitrogen source: $10 \mathrm{~g} / \mathrm{dm}^{3} ; \mathrm{b}$ - simultaneous usage of biogas, $101.3 \mathrm{kPa}$ and solid $\mathrm{MgCO}_{3}: 25 \mathrm{~g} / \mathrm{dm}^{3}$, yeast extract used as nitrogen source at total dosage $10 \mathrm{~g} / \mathrm{dm}^{3}$ ).

During the second part of the experiment, simultaneous effect of gaseous $\mathrm{CO}_{2}$ and solid $\mathrm{MgCO}_{3}$ on the performance of succinic fermentation, was taken into account. When $\mathrm{MgCO}_{3}$ was added with the supply of gaseous $\mathrm{CO}_{2}$; the following compounds: $\mathrm{CO}_{2}, \mathrm{HCO}_{3}{ }^{-}$and $\mathrm{CO}_{3}{ }^{2-}$ would become in the equilibrium in the fermentation broth [15]. The highest succinic titer and yield amounted to $22-23 \mathrm{~g} / \mathrm{dm}^{3}$ and $73-74 \%$, respectively and these values were obtained for $\mathrm{MgCO}_{3}$ dosage of $25-30 \mathrm{~g} / \mathrm{dm}^{3}$ (300-400 $\mathrm{mM} \mathrm{CO}_{2}$ ) (data equivalent statistically, data statistically equivalent, $p>0.05$ ) (Table I). Slightly lower succinic yields were recorded for $\mathrm{MgCO}_{3}$ dosage of $20 \mathrm{~g} / \mathrm{dm}^{3}$ (Table I). In these conditions, the dosage of carbon sources significantly exceeded the maximum $\mathrm{CO}_{2}$ solubility (139 $\mathrm{mM})$ [15]. This proves that high succinic yields are obtained in conditions of excess $\mathrm{CO}_{2}$ content. This is in accordance with previous reports stating that the highest succinic yields $(69-71 \%, 0.69-0.71 \mathrm{~g} / \mathrm{g})$ were obtained for carbonate dosage of $300-500 \mathrm{mM}$ [17]. Obtained succinic yields are within the values most commonly reported for lignocellulosic hydrolysates [2], [12]. It should be highlighted that maximal theoretical molar yield of succinic acid per mole of glucose corresponds to 1.71 (12/7) (Eq. (1)) and this equation equals to $1.12 \mathrm{~g} / \mathrm{g}$ when expressed as a mass unit. This theoretical maximal yield would be achieved anaerobically and represents a theoretical situation where the microorganisms do not use substrate for growth, maintenance or an external electron acceptor.

$$
\mathrm{C}_{6} \mathrm{H}_{12} \mathrm{O}_{6}+\frac{6}{7} \mathrm{CO}_{2} \rightarrow \frac{12}{7} \mathrm{C}_{4} \mathrm{H}_{6} \mathrm{O}_{4}+\frac{6}{7} \mathrm{H}_{2} \mathrm{O}
$$

Based on our results, it can be stated that the availability of $\mathrm{CO}_{2}$ is crucial for the bio-succinic acid production, and $A$. succinogenes consumes $\mathrm{CO}_{2}$ during fermentation. The stoichiometric reaction cited above suggests that $1 \mathrm{~kg}$ of succinic acid will utilize $0.37 \mathrm{~kg}$ of $\mathrm{CO}_{2}$. Therefore, it is evident that bio-succinic acid production could contribute to the abatement of $\mathrm{CO}_{2}$ emissions. An additional purpose of using $\mathrm{CO}_{2}$ for biosynthesis of succinic acid was to purify the biogas used as $\mathrm{CO}_{2}$ source. $\mathrm{CH}_{4}$ content in biogas after succinic fermentation with gaseous $\mathrm{CO}_{2}$ source increased by $10-11 \%$ and reached the level of $82-84 \% \pm 1.5 \%$. There was no a significant impact of increased $\mathrm{CO}_{2}$ pressure on the final $\mathrm{CH}_{4}$ content in biogas $(88 \% \pm 1.5 \%)$ (Table II). An increase of $\mathrm{CH}_{4}$ content from $85 \%$ to $95 \%$ was reported in previous studies [6]. However, as previously mentioned, these authors used biogas containing significantly higher $\mathrm{CO}_{2}$ content $(40 \%$ vol.) compared to present study ( $25 \%$ vol.). As regards the simultaneous usage of gaseous $\mathrm{CO}_{2}$ and $\mathrm{MgCO}_{3}$ (dosage of $\left.25-30 \mathrm{~g} / \mathrm{dm}^{3}\right)$, it was observed that $\mathrm{CH}_{4}$ content after succinic fermentation, was not significantly increased (76-77\% vol.). Such conditions reflected high $\mathrm{CO}_{2}$ content, originated from carbonate. Whilst, the $\mathrm{CH}_{4}$ content in biogas increased by 21-23\% with a lower dosage of $\mathrm{MgCO}_{3}\left(15-20 \mathrm{~g} / \mathrm{dm}^{3}\right)$ (Table II). In these cases, the final $\mathrm{CH}_{4}$ content in biogas treated is in consistence with values possible to obtain via commercially available purification methods, e.g. biogas treatment with water scrubbing or using chemical scrubbers with amine solutions [18].

All in all, these results proves the positive impact of simultaneous addition of gaseous $\mathrm{CO}_{2}$ and solid $\mathrm{MgCO}_{3}$ on the course of succinic fermentation, both in regards of succinic yield and biogas purification (Table II). What is more, fermentation with simultaneous $\mathrm{CO}_{2}$ source (biogas $/ \mathrm{MaCO}_{3}$ ) resulted in almost $90 \%$ sugar utilization, with complete glucose consumption and about $50 \%$ 
bioconversion of xylose into carboxylic acids. Whereas, the process with biogas as the only $\mathrm{CO}_{2}$ source resulted in significant residual glucose and almost $70 \%$ of initial xylose present in the solution (Fig. 1). This proves that Actinobacillus succinogenes prefers glucose as substrate rather than $\mathrm{C}_{5}$ sugars (e.g. xylose) [11], [12].

TABLE II: INFLUENCE OF SUCCINIC FERMENTATION ON BIOGAS COMPOSITION

\begin{tabular}{||l||c||c||}
\hline \hline $\mathrm{CO}_{2}$ source & $\begin{array}{c}\mathrm{CH}_{4} \\
\text { (\% vol. })\end{array}$ & $\begin{array}{c}\mathrm{CO}_{2} \\
\text { (\% vol. })\end{array}$ \\
\hline \hline Biogas $(101.3 \mathrm{kPa})$ & $76.3 \pm 2.0$ & $21.8 \pm 1.8$ \\
\hline \hline Biogas $(140 \mathrm{kPa})$ & $82.1 \pm 2.0$ & $15.4 \pm 1.8$ \\
\hline \hline Biogas $(140 \mathrm{kPa})+15 \mathrm{~g} / \mathrm{dm}^{3} \mathrm{MgCO}_{3}$ & $91.8 \pm 2.2$ & $5.17 \pm 1.2$ \\
\hline \hline Biogas $(140 \mathrm{kPa})+20 \mathrm{~g} / \mathrm{dm}^{3} \mathrm{MgCO}_{3}$ & $91.3 \pm 2.0$ & $5.97 \pm 1.3$ \\
\hline \hline Biogas $(140 \mathrm{kPa})+25 \mathrm{~g} / \mathrm{dm}^{3} \mathrm{MgCO}_{3}$ & $78.8 \pm 2.5$ & $17.1 \pm 2.0$ \\
\hline \hline Biogas $(140 \mathrm{kPa})+30 \mathrm{~g} / \mathrm{dm}^{3} \mathrm{MgCO}_{3}$ & $77.5 \pm 2.1$ & $17.3 \pm 2.0$ \\
\hline
\end{tabular}

Depending on succinic fermentation conditions, including type of $\mathrm{CO}_{2}$ source and its dosage, other metabolites, such as acetic, formic, lactic acid or ethanol, can be produced in different amounts [19]. In the present study, acetic- and formic acid were produced as the main fermentation by-products. In the initial growth phase, succinic, acetic and formic acids were simultaneously produced. It was noticed that during succinic fermentation with biogas as the only $\mathrm{CO}_{2}$ source; by-products (acetic and formic acids) content significantly exceeded $30 \%$ of total fermentation products (succinic, acetic and formic acid) (Table I).

As compared to the succinic acid, which is formed via $\mathrm{C}_{4}$ pathway, i.e. carboxylation of phosphoenolpyruvate and NADH (nicotinamide adenine dinucleotide) consumption within the reductive branch of TCA cycle), - acetic and formic acids are formed via $\mathrm{C}_{3}$ pathway [20]. By-products concentration (acetic and formic acids) during fermentation with $\mathrm{MgCO}_{3}$ or $\mathrm{MgCO}_{3}$ +biogas was stable and did not exceed $30 \%$ of total fermentation products (succinic, acetic and formic acid, Table I). This showed that applied $\mathrm{CO}_{2}$ concentration was enough to increase $\mathrm{C}_{4}$ flux towards higher succinic acid production.

\section{B. Succinic Fermentation Using Different Nitrogen Sources}

Fermentation with yeast extract as a nitrogen source started without any lag phase and higher values of sugar utilization and succinic titers were obtained after application of higher yeast extract dosage (i.e. $10 \mathrm{~g} / \mathrm{dm}^{3}$ ) compared to dosage of $5 \mathrm{~g} / \mathrm{dm}^{3}$ (Table III). This shows that yeast extract is a favorable component of medium, used for bio-succinic synthesis. However, yeast extract is considered as one of the most expensive medium component (200 USD/kg of extract suitable for microbial growth) [21]. Based on the results obtained, it was concluded that fermentation assays containing mixtures of yeast extract/rapeseed cakes, in which at least $50 \%$ of yeast extract was present, also started without any lag phase. In such cases, sugar utilization and succinic yields amounted to $84-87 \%$ and $67-68 \%$ (Table III) (data statistically equivalent, $p>0.05$ ). This is in accordance with previous studies stating that rapeseed meal (e.g. pretreated by dilute acid method and hydrolysed with pectinase) can be used as carbon and nitrogen source, for production of succinic acid by A. succinogenes [22]. Significantly higher residual sugar contents and lower succinic yields were obtained after application of more than $50 \%$ of rapeseed cakes as nitrogen dosage (Table III), which proves that it is difficult to completely replace yeast extract in the original fermentation medium, by rapeseed cakes as nitrogen sources. Yeast extract, being rich in amino acids, vitamins and trace elements is considered as favorable nitrogen source in fermentation processes.

TABLE III: INFLUENCE OF NITROGEN SOURCE ON SUCCINIC ACID

\begin{tabular}{||l||l||c||c||c||}
\multicolumn{1}{|c|}{ PRODUCTION } \\
\hline $\begin{array}{c}\text { YE:RK } \\
(\% \mathbf{w} / \mathbf{w})\end{array}$ & $\begin{array}{l}\text { Sugar util. } \\
(\%)\end{array}$ & $\begin{array}{c}\text { Succinic acid } \\
\left(\mathrm{g} / \mathrm{dm}^{3}\right)\end{array}$ & $\begin{array}{c}\text { Succinic } \\
\text { yield }(\%)\end{array}$ & $\begin{array}{c}\text { Byproducts } \\
(\%)\end{array}$ \\
\hline \hline $100: 0^{\mathrm{a}}$ & $81.7 \pm 3.0 \mathrm{ab}$ & $14.6 \pm 1.0 \mathrm{~b}$ & $54.5 \pm 1.8 \mathrm{~b}$ & $32.6 \pm 1.8 \mathrm{~b}$ \\
\hline \hline $100: 0^{\mathrm{b}}$ & $89.3 \pm 1.5 \mathrm{a}$ & $19.2 \pm 1.4 \mathrm{a}$ & $65.2 \pm 3.2 \mathrm{a}$ & $27.1 \pm 2.0 \mathrm{~b}$ \\
\hline \hline $80: 20^{\mathrm{b}}$ & $86.8 \pm 1.7 \mathrm{a}$ & $19.3 \pm 0.6 \mathrm{a}$ & $67.7 \pm 1.7 \mathrm{a}$ & $28.8 \pm 1.7 \mathrm{~b}$ \\
\hline \hline $60: 40^{\mathrm{b}}$ & $86.8 \pm 1.8 \mathrm{a}$ & $19.2 \pm 1.2 \mathrm{a}$ & $67.1 \pm 3.4 \mathrm{a}$ & $29.0 \pm 1.8 \mathrm{~b}$ \\
\hline \hline $50: 50^{\mathrm{b}}$ & $83.8 \pm 1.7 \mathrm{a}$ & $18.8 \pm 1.0 \mathrm{a}$ & $68.3 \pm 2.9 \mathrm{a}$ & $30.4 \pm 1.6 \mathrm{~b}$ \\
\hline \hline $40: 60^{\mathrm{b}}$ & $74.6 \pm 3.5 \mathrm{~b}$ & $15.4 \pm 1.0 \mathrm{~b}$ & $61.9 \pm 3.2 \mathrm{ab}$ & $39.1 \pm 1.7 \mathrm{a}$ \\
\hline
\end{tabular}

(a - total nitrogen source of $5 \mathrm{~g} / \mathrm{dm}^{3}$, b- total nitrogen source of $10 \mathrm{~g} / \mathrm{dm}^{3}$, $\mathrm{YE}$ - yeast extract, RK - rapeseed cakes, average values $\mathrm{n}=3, \pm$ standard deviation, the same letters represent data equivalent statistically $\mathrm{p}>0.05$ )
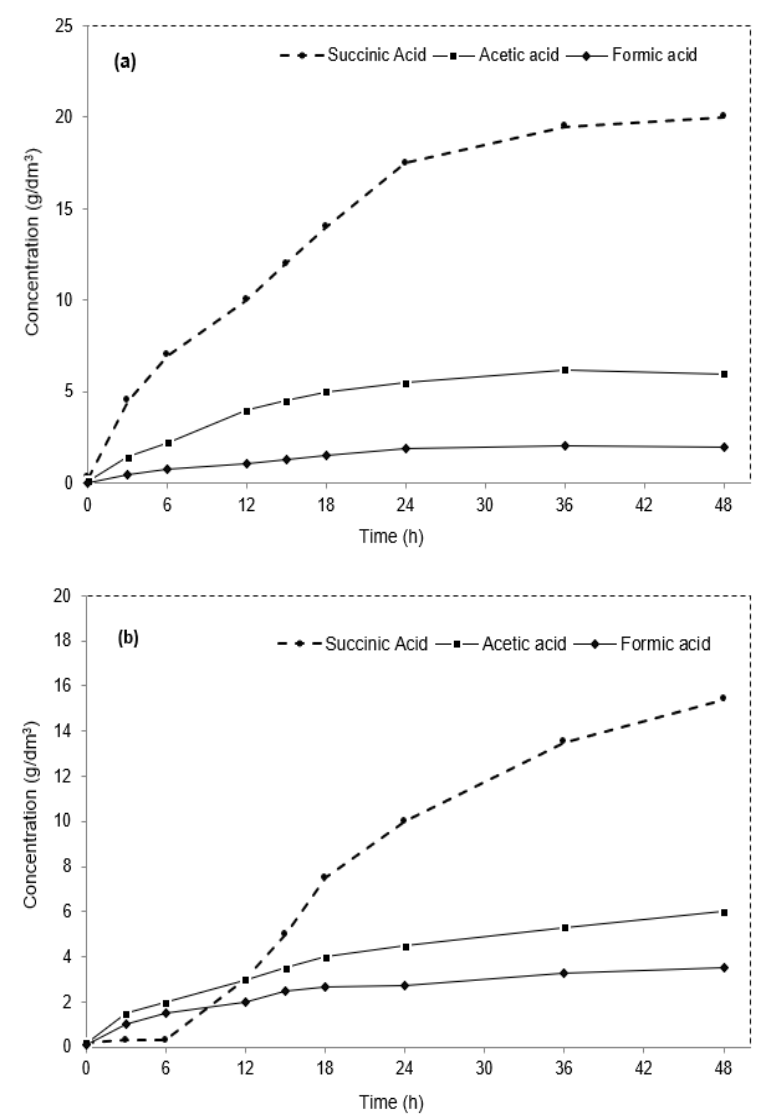

Fig. 2. Influence of nitrogen source on the course of succinic fermentation (a - fermentation with ratio of yeast extract to rapeseed cakes 50:50, b fermentation with ratio of yeast extract to rapeseed cakes 40:60; nitrogen dosage in both analyzed processes: $10 \mathrm{~g} / \mathrm{dm}^{3}$ ).

Succinic fermentation with addition of more than $50 \%$ of rapeseed cakes resulted in increased production of acetic and formic acids (by-products of succinic fermentation) (Fig. 2). What is more, succinic production started with a $6 \mathrm{~h}$ lag phase after addition of $60 \%$ nitrogen dosage as rapeseed cakes (Fig. 2). During the first hours of fermentation, by-products (acetic and formic acids) significantly exceeded succinic production. Such disturbances in succinic fermentation were not 
observed after addition of $\leq 50 \%$ nitrogen dosage as rapeseed cakes. After 18-24 h of the process, the production of acetic and formic acids ceased, which is connected with low cell-biomass generation during stationary phase and consequently lower energy requirements [3]. In this case, carbon flux shifts towards succinic acid production (Fig. 2). It should be mentioned that increased by-products concentration in fermentation broths influences negatively the final product (succinic acid) separation. It is estimated that downstream processing of succinic acid can make more than $50-60 \%$ of total costs and is attributed to recovery and refining [6]. Acetic and formic acids can be effectively removed via vacuum distillation as their boiling points are significantly lower than boiling point of succinic acids [23].

Based on the results presented, it can be stated that rapeseed cakes can be used as component of fermentation medium and partially $(\leq 50 \%)$ replace yeast extract. It is in accordance with other reports stating that alternative nitrogen sources are not able to completely eliminate yeast extract during succinic fermentation, e.g. by addition of corn steep liquor (CLS). In this study, it was found that this substrate could not completely replace enriched yeast extract without adding additional ingredients in order to meet physiological demands of A. succinogenes [24].

\section{CONCLUSION}

The results obtained in this study clearly confirmed that hydrolisates obtained from Miscanthus $\times$ giganteus after glycerol pretreatment can be considered as a promising feedstock for succinic acid production. The study focused on two the most important process parameters, which influence succinic yields and sugar conversion rates: carbon dioxide availability and nitrogen source.

1) These results proved the positive impact of simultaneous addition of gaseous $\mathrm{CO}_{2}$ (biogas) and solid $\mathrm{MgCO}_{3}$ on the course of succinic fermentation and succinic yield.

2) Costly yeast extract used during succinic fermentation can be successfully replaced $(\leq 50 \%$ of its dosage) by rapeseed cakes, i.e. a residual material from pressing of oil from rapeseed.

However, the complex composition of oil cakes requires further research to confirm which component (of organic nitrogen) has the most significant impact on the effectiveness of succinic acid and other metabolites production. Further research should also include an effective concept of succinic broths purification and downstream processes, which would allow to obtain succinic acid (>98\%) suitable for further chemical transformations.

\section{CONFLICT OF INTEREST}

The authors declare no conflict of interest.

\section{AUTHOR CONTRIBUTIONS}

M. Kuglarz conducted the research on succinic fermentation using different carbon and nitrogen sources as well as analyzed hydrolysates and final products in succinic broths, using HPLC method. M. Kuglarz also prepared the manuscript for publication; M. Rom prepared hydrolysates for succinic fermentation, participated in hydrolysates analyses (carbohydrate, final products) and developed statistical evaluation of obtained results. All authors had approved the final version.

\section{ACKNOWLEDGMENT}

We would like to thank Dr Klaudiusz Grübel from Faculty of Materials, Civil and Environmental Engineering, University of Bielsko-Biala, Poland, for his help connected with samples autoclaving before succinic fermentation. Authors allow the readers to perform similar experiments or calculations and use the reported results.

\section{REFERENCES}

[1] H. Song and S. Y. Lee, "Production of succinic acid by bacterial fermentation," Enzyme Microb. Technol., vol. 39, no. 3, 39, pp. 352-361, July 2006.

[2] J. Becker, A. Lange, J. Fabarius, and C. Wittmann, "Top value platform chemicals: Bio-based production of organic acids," Current Opinion in Biotechnology," vol. 36, pp. 168-175, December 2015.

[3] C. Pateraki et al., "Actinobacillus succinogenes: advances on succinic acid production and prospects for development of integrated biorefineries," Biochem. Eng. J., vol. 112, pp. 285-303, August 2016.

[4] W. Dessie et al., "Opportunities, challenges, and future perspectives of succinic acid production by Actinobacillus succinogenes," Appl. Microbiol. Biotechnol., vol. 102, no. 23, pp. 9893-9910, December 2018.

[5] K. K. Cheng, X. B. Zhao, J. Zeng, and J. A. Zhang, "Biotechnological production of succinic acid: current state and perspectives," Biofuels Bioprod. Biorefin., vol. 6, no. 3, pp. 302-318, May 2012.

[6] I. B. Gunnarsson, M. Alvarado-Morales, and I. Angelidaki, "Utilization of $\mathrm{CO}_{2}$ fixating bacterium Actinobacillus succinogenes $130 \mathrm{Z}$ for simultaneous biogas upgrading and biosuccinic acid production," Environ. Sci. Technol., vol. 48, no. 20, pp. 12464-12468, December 2014.

[7] K. Zhang, Z. J. Pei, and D. H. Wang, "Organic solvent pretreatment of lignocellulosic biomass for biofuels and biochemicals: A review," Bioresour. Technol., vol. 199, pp. 21-33, January 2016.

[8] J. H. Choi et al., "Simultaneous production of glucose, furfural, and ethanol organosolv lignin for total utilization of high recalcitrant biomass by organosolv pretreatment," Renew. Energy, vol. 130, pp. 952-960, January 2019.

[9] A. B. Diaz et al., "Evaluation of microwave-assisted pretreatment of lignocellulosic biomass immersed in alkaline glycerol for fermentable sugars production," Bioresour. Technol., vol. 185, pp. 316-323, June 2015 ,

[10] X. J. Lv et al., "Enhanced enzymatic saccharification of sugarcane bagasse pretreated by sodium methoxide with glycerol," Bioresour. Technol., vol. 249, pp. 226-233, February 2018.

[11] K. Dąbkowska, M. Alvarado-Morales, M. Kuglarz, and I. Angelidaki, "Miscanthus straw as substrate for biosuccinic acid production: Focusing on pretreatment and downstream processing," Bioresour. Technol., vol. 278, pp. 82-91, April 2019.

[12] I.B. Gunnarsson, M. Kuglarz, D. Karakashev, and I. Angelidaki, "Thermochemical pretreatments for enhancing succinic acid production from industrial hemp (Cannabis sativa L.)," Bioresour. Technol., vol. 182, pp. 58-66, April 2015.

[13] M. Kuglarz, "Mesophilic wastes co-digestion enhanced by application of microwave radiation," Ph.D. dissertation, Faculty of Energy and Envir. Eng., Silesian University of Technology, Gliwice, 2012.

[14] H. Pińkowska, P. Wolak, and E. Oliveros, "Hydrothermolysis of rapeseed cake in subcritical water. Effect of reaction temperature and holding time on product composition," Biomass Bioenergy, vol. 64, pp. 50-61, May 2014.

[15] W. Zou, L. W. Zhu, H. M. Li, and Y. J. Tang, "Significance of $\mathrm{CO}_{2}$ donor on the production of succinic acid by Actinobacillus succinogenes ATCC 55618," Microb Cell Fact., vol. 87, no. 10, pp. 1-10. October 2011.

[16] Y. P. Liu, Z. H. Sun, Y. Ni, J. J. Dong, and P. Wei, "Strategies of pH control and glucose-fed batch fermentation for production of succinic acid by Actinobacillus succinogenes CGMCC1593," J. Chem. Technol. Biotechnol., vol. 83, no. 5, pp. 722-729, May 2008.

[17] J. P. Tan, A. A. I. Luthfi, S. F. A. Manaf, T. Y. Wu, and J. M. Jahim "Incorporation of $\mathrm{CO}_{2}$ during the production of succinic acid from 
sustainable oil palm frond juice," Journal of $\mathrm{CO}_{2}$ Utilization, vol. 26, pp. 595-601, July 2018

[18] O. W. Awe, Y. Zhao, A. Nzihou, D. P. Minh, and N. Lyczko, "A review of biogas utilisation, purification and upgrading technologies," Waste Biomass Valor., vol. 8, no. 2, pp. 267-283, March 2017.

[19] J. B. McKinlay, J. G. Zeikus, and C. Vieille, "Insights into Actinobacillus succinogenes fermentative metabolism in a chemically defined growth medium," Appl. Environ. Microbiol., vol. 71, no. pp. 6651-6656, December 2005.

[20] M. Carvalho, C. Roca, and M. A. Reis, "Improving succinic acid production by Actinobacillus succinogenes from raw industrial carob pods," Bioresour Technol., vol. 218, pp. 491-497, October 2016.

[21] I. Eş, A. M. Khaneghah, F. J. Barba, J. A. Saraiva, A. S. Sant'Ana, and S. M. B. Hashemi, "Recent advancements in lactic acid production A review," Food Research International, vol. 107, pp. 763-770, May 2018.

[22] K. Chen, H. Zhang, Y. Miao, P. Wei, and J. Chen, "Simultaneous saccharification and fermentation of acid-pretreated rapeseed meal for succinic acid production using Actinobacillus succinogenes," Enzyme Microb Technol., vol. 48, no. 4-5, pp. 339-344, April 2011.

[23] A. Vlysidis, M. Binns, C. Webb, and C. Theodoropoulos, "Glycerol utilisation for the production of chemicals: Conversion to succinic acid, a combined experimental and computational study," Biochem. Eng. J., vol. 58-59, pp. 1-11, December 2011.

[24] N. Shen et al., "Production of succinic acid from sugarcane molasses supplemented with a mixture of corn steep liquor powder and peanut meal as nitrogen sources by Actinobacillus succinogenes," Lett. Appl. Microbiol., vol. 60, no. 6, pp. 544-551, June 2015.

Copyright $\odot 2019$ by the authors. This is an open access article distributed under the Creative Commons Attribution License which permits unrestricted use, distribution, and reproduction in any medium, provided the original work is properly cited (CC BY 4.0).

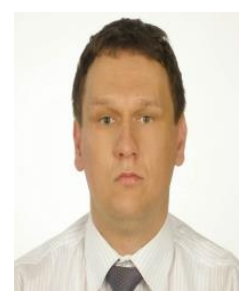

M. Kuglarz is Ph.D. in technical sciences, discipline: environmental engineering, Silesian University of Technology, Faculty of Energy and Environmental Engineering, Poland, degree given by the Resolution of the Faculty Council, 24 February 2012. He worked as quest post-doc during didactic and scientific internship at Technical University of Denmark, DTU Environmental Engineering, April to October 2012 He participated in an internship and training program "TOP 500 Innovators Science-Management-Commercialization Program", Haas School of Business, University of California, Berkeley, USA, 9 weeks (May-July 2013). Later, he took part in research exchange at Technical University of Denmark, DTU Environmental Engineering, 5 visits (2015-2018), at the invitation of a foreign institution. He is now employed at University of Bielsko-Biala, Faculty of Materials, Civil and Environmental Engineering, Institute of Environmental Protection and Engineering, Poland, current position, assistant professor and senior researcher. His scientific and research activity includes more than 60 scientific publications, including 15 publications in journals included in the database of Journal Citation Reports (JCR); total impact factor (IF): 40,825 (all obtained after Ph.D degree). He participated in 24 scientific conferences (international and national), delivered 7 oral speeches and presented 17 posters. In 2018, he was awarded for the best presentation during a conference, organized by Elsevier (BIORESTEC 2018 Best Poster Awards). His involvement in professional activities was honored with 4 Rector's Awards (2010-2014, 2016, 2017, 2018), including the category "for obtaining the highest value of IF index (impact factor)", in the University scale.

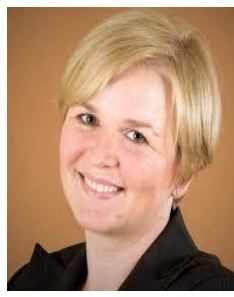

Monika Rom is researcher and laboratory specialist. She has more than 10 years of experience. She is also a trainer in prestigious program Top Minds, an initiative of Association Top 500 Innovators and the Polish-American Fulbright Commission. She has been working on different aspects of environmental engineering, including feedstock compositional analyses. She is the member of TOP 500 Association of Innovators, participated in several post-doctoral programs, including: 9 week Science-Management-Innovation program at University of California, Berkeley (edition 2012). 